\title{
What We Owe Each Other
}





\section{MINOUCHE SHAFIK}

\section{What We Owe Each Other \\ A New Social Contract for a Better Society}




\section{Copyright (C) 202I by Nemat (Minouche) Shafik}

Princeton University Press is committed to the protection of copyright and the intellectual property our authors entrust to us. Copyright promotes the progress and integrity of knowledge. Thank you for supporting free speech and the global exchange of ideas by purchasing an authorized edition of this book. If you wish to reproduce or distribute any part of it in any form, please obtain permission.

Requests for permission to reproduce material from this work should be sent to permissions@press.princeton.edu

Published in the United States and Canada by Princeton University Press

4I William Street, Princeton, New Jersey o8 540

press.princeton.edu

First published in the United Kingdom by

The Bodley Head, an imprint of Vintage, in 202I

All Rights Reserved

Library of Congress Control Number 2020952245

ISBN 978-0-69I-20445-I

ISBN (e-book) 978-0-69I-22027-7

Typeset in II.5/I 5 pt Sabon LT Std

by Integra Software Services Pvt. Ltd, Pondicherry

Jacket design by Hillary Leone and Darina Karpov / Cabengo Jacket image: Shutterstock

Printed on acid-free paper. $\infty$

Printed in the United States of America

I 35579 IO 86442 
For Adam, Hanna, Hans-Silas, Maissa, Nora, Olivia and Raffael 
